\title{
Pengaruh Penyakit Infeksi terhadap Kadar Albumin Anak Gizi Buruk
}

\author{
Nur Aisiyah Widjaja, Siti Nurul Hidayati, Roedi Irawan \\ Departemen Ilmu Kesehatan Anak Fakultas Kedokteran Universitas Airlangga/RSUD Dr.Soetomo, \\ Surabaya
}

Latar belakang. Penyakit infeksi dan gizi buruk merupakan hubungan yang sinergis. Serum albumin merupakan prognostik faktor yang penting untuk pasien gizi buruk terutama yang dirawat di rumah sakit. Pasien rawat inap dengan gizi buruk mempunyai risiko komplikasi klinis yang lebih berat, dan mortalitas lebih tinggi dibanding pasien tanpa gizi buruk.

Tujuan. Mengetahui pengaruh penyakit infeksi terhadap kadar albumin anak dengan gizi buruk yang dirawat di rumah sakit.

Metode. Penelitian analitik deskriptif retrospektif dari data sekunder status semua pasien gizi buruk dengan atau tanpa edema yang dirawat di bangsal anak RSUD Dr Soetomo, Surabaya sejak Mei tahun 2008-Juni 2009. Data yang diambil adalah data umur, jenis kelamin, dan status penyakit. Pasien dibagi dua kelompok, yaitu kelompok infeksi dan non infeksi, dan diukur kadar albuminnya. Analisis data menggunakan chisquare dan $t$-test.

Hasil. Didapatkan 77 anak dengan gizi buruk tipe non edema, 44 anak dengan penyakit infeksi dan 33 anak dengan penyakit non infeksi. Nilai rerata albumin pada anak gizi buruk dengan infeksi lebih rendah dan bermakna secara statistik dibandingkan gizi buruk non infeksi $(3,08 \pm 0,74 \mathrm{~g} / \mathrm{dL}$ dibanding 3,56 $\pm 0,99 \mathrm{~g} / \mathrm{dL}$, $\mathrm{p}=0,019)$. Anak gizi buruk dengan serum albumin rendah mempunyai risiko untuk mendapatkan penyakit infeksi lebih tinggi dibanding anak gizi buruk tanpa penyakit infeksi (RR:1,35, CI 95\%:1,030-1,946).

Kesimpulan. Kadar serum albumin yang rendah pada anak gizi buruk yang dirawat di rumah sakit lebih berisiko untuk mendapatkan infeksi. Sari Pediatri 2013;15(1):46-50.

Kata kunci: anak gizi buruk, kadar serum albumin, infeksi

\footnotetext{
Alamat korespondensi:

Dr. Nur Aisiyah Widjaja, Sp.A. Staf Divisi Nutrisi dan Penyakit Metabolik Departemen Ilmu Kesehatan Anak FK Unair/RSUD Dr.Soetomo Surabaya. Jl.Prof.Dr.Moestopo 6-8 Surabaya,Telp (031) 5501682. E-mail: nurilo8@yahoo.com
}

nak dengan gizi buruk yang dirawat di
rumah sakit berisiko untuk mendapat
komplikasi klinis yang berat. ${ }^{1}$ Beberapa
penelitian menyatakan bahwa serum albu- 
dirawat inap mempunyai kadar albumin yang rendah sehingga dapat memperburuk prognosis penyakitnya. ${ }^{1}$ Dipertimbangkan untuk pemberian nutrisi yang adekuat, untuk mendukung kecukupan kadar albumin dalam tubuhnya. ${ }^{2,3}$

Serum albumin merupakan indeks nutrisi yang banyak dipakai sebagai pemeriksaan pada populasi karena mudah diukur dan berhubungan dengan risiko mortalitas pada berbagai penyakit. ${ }^{1,4}$ Kadar albumin yang rendah berhubungan dengan risiko peningkatan morbiditas dan mortalitas pasen yang dirawat. ${ }^{5}$ Pada anak gizi buruk terjadi penurunan sintesis dan pemecahan protein total tubuh. Hal tersebut disebabkan proses adaptasi terhadap keadaan energi yang kurang pada anak gizi buruk $k^{5,6}$

Pertahanan sistem alamiah tubuh terdiri dari protein yang dapat dipecah dan berikatan dengan produk bakteri. ${ }^{7}$ Sirkulasi protein tersebut penting untuk mengenali produk bakteri oleh leukosit yang berfungsi untuk fagositosis dan membunuh bakteri. ${ }^{7}$ Anak gizi buruk mempunyai rerata penurunan sintesis protein total dan peningkatan pemecahan yang menyebabkan penurunan kadar albumin dalam tubuh. ${ }^{8}$ Penurunan kadar albumin dalam tubuh berhubungan dengan peningkatan risiko infeksi. ${ }^{9}$

Albumin merupakan serum protein cadangan dalam tubuh yang diproduksi oleh hati. Secara normal, albumin merupakan 55\% dari semua protein plasma. Jumlah albumin untuk penilaian status nutrisi adalah normal 3,5-4,7 g/dL kekurangan ringan 2,8-3,4 g/dL kekurangan sedang 2,1-2,7 g/dL, kekurangan berat < $2,1 \mathrm{~g} / \mathrm{dL} .{ }^{3,6}$

Secara umum banyak klinisi masih sering menggunakan pemeriksaan tersebut untuk menilai status nutrisi. ${ }^{1}$ Faktor utama yang berpengaruh terhadap konsentrasi plasma albumin pada pasien adalah rerata pengeluaran transkapiler ke dalam cairan intersisial. ${ }^{1}$ Pengeluaran transkapiler menyebabkan peningkatan risiko penyakit (bagian dari SIRS) yang akan menyebabkan penurunan konsentrasi albumin plasma. ${ }^{4} \mathrm{Hal}$ tersering terjadi pada pasien dengan infeksi yang berat sering terdapat penurunan kadar albumin. Semakin berat penyakit infeksinya menyebabkan penurunan albumin dan memperburuk prognosis. ${ }^{4,5}$

Penelitian bertujuan untuk mengetahui pengaruh penyakit infeksi terhadap kadar albumin anak dengan gizi buruk yang dirawat di rumah sakit sehingga perlu waspada terhadap dukungan nutrisi terutama protein yang cukup supaya tidak mendapat komplikasi lanjut dan memerlukan waktu lebih lama untuk tinggal di rumah sakit.

\section{Metode}

Data sekunder berasal dari status rawat inap di ruang perawatan anak RS Dr. Soetomo, Surabaya sejak Mei 2008 sampai Juni 2009. Kriteria inklusi adalah semua anak yang sudah didiagnosis gizi buruk dan dirawat. Dari semua pasien gizi buruk, dibedakan menjadi dua kelompok, yaitu kelompok gizi buruk dengan penyakit infeksi, dan kelompok gizi buruk pada penyakit non infeksi. Diagnosis penyakit infeksi berdasarkan kompetensi klinis dokter spesialis anak di ruangan perawatan, dan didukung pemeriksaan laboratorium serta radiologis sesuai dengan penyakitnya.

Kriteria eksklusi adalah penyakit infeksi berat (HIV, sepsis). Sedangkan kriteria eksklusi untuk penyakit non infeksi adalah kelainan genetik (sindrom atau kelainan kongenital) keganasan, kelainan darah, penyakit hati, dan penyakit endokrin. Karakteristik kadar albumin dibandingkan di antara kedua kelompok tersebut.

Pengambilan data dilakukan melalui lembar pengumpulan data (LPD) secara retrospektif dari rekam medis. Variabel yang dianalisis meliputi umur, jenis kelamin, pemeriksaan antropometri, nilai hemoglobin, leukosit, dan albumin.

Penilaian status gizi buruk menggunakan berat badan menurut tinggi badan CDC 2000 dengan kriteria waterlow $<70 \%$. Hasil pemeriksaan hemoglobin, leukosit, dan albumin dilakukan berdasarkan laboratorium Patologi Klinik RS. Dr. Soetomo, serta dilakukan pada saat pasien dirawat.

Analisis statistik yang digunakan adalah uji t untuk data kuantitatif dan uji chi-square untuk data kualitatif dengan confidence interval (CI) 95\%. Hubungan antar variabel dinyatakan signifikan apabila $\mathrm{p}<0,05$.

\section{Hasil}

Didapatkan total 77 pasien gizi buruk yang terdiri dari 45 pasien gizi buruk dengan penyakit infeksi, dan 32 pasien gizi buruk dengan penyakit non infeksi. Tabel 1 menunjukkan distribusi umur, jenis kelamin, 
Nur Aisiyah Widjaja dkk: Pengaruh penyakit infeksi terhadap kadar albumin anak gizi buruk

Tabel 1.Karakteristik umur, jenis kelamin, dan persentase BB ideal antara dua kelompok

\begin{tabular}{lccc}
\hline Parameter & $\begin{array}{c}\text { Kelompok } \\
\text { Infeksi }\end{array}$ & $\begin{array}{c}\text { Kelompok } \\
\text { Non Infeksi }\end{array}$ & \multirow{2}{*}{$\mathrm{p}$} \\
\cline { 2 - 3 } & Rerata \pm SD & Rerata \pm SD & \\
\hline Jenis kelamin & & & \\
Laki laki & 19 & 20 & \\
$\quad$ Perempuan & 26 & 12 & \\
Umur (bulan) & $30,26 \pm 39,29$ & $40,63 \pm 52,93$ & 0,356 \\
$\%$ BBI & $64,81 \pm 4,70$ & $64,46 \pm 5,48$ & 0,762 \\
\hline
\end{tabular}

*signifikan bila $\mathrm{p}<0.05$

Tabel 2. Jenis penyakit infeksi dan non infeksi

\begin{tabular}{lc}
\hline Subyek & Jumlah (\%) \\
\hline Gizi buruk non infeksi & \\
Kelainan jantung & $27(84,37)$ \\
Gizi buruk tanpa penyakit & $5(15,62)$ \\
Gizi buruk dengan penyakit infeksi & \\
Diare akut & $19(42,22)$ \\
Infeksi saluran napas atas & $5(11,11)$ \\
Infeksi saluran napas bawah & $12(26,66)$ \\
Tuberkulosis & $4(8,88)$ \\
Infeksi saluran kencing & $5(11,11)$ \\
\hline
\end{tabular}

30,26 (SB 39,29) bulan pada kelompok gizi buruk dengan penyakit infeksi dan 40,63 (SB 52,93) bulan pada kelompok gizi buruk dengan penyakit non infeksi. Rerata persentase berat badan ideal pada kelompok gizi buruk dengan penyakit infeksi 64,81 (SB 4,70) dan 64,46 (SB 5,48) pada penyakit non infeksi. Secara statistik tidak ada perbedaan antara dua kelompok tersebut.

Jenis penyakit infeksi terbanyak yang menyertai gizi buruk adalah diare akut $(42,22 \%)$, selanjutnya berturut turut infeksi saluran napas bawah, saluran

Tabel 3. Perbandingan hemoglobin, leukosit, dan albumin antara dua kelompok

\begin{tabular}{lccc}
\hline Kelompok & $\begin{array}{c}\text { Kelompok infeksi } \\
\text { Rerata } \pm \text { SB }\end{array}$ & $\begin{array}{c}\text { Kelompok non infeksi } \\
\text { Rerata } \pm \text { SB }\end{array}$ & $\mathrm{p}$ \\
\hline Hemoglobin $\mathrm{g} \%$ & $10,74 \pm 2,71$ & $10,7 \pm 2,41$ & 0,940 \\
Leukosit $/ \mathrm{uL}$ & $12.975,00 \pm 8.649,71$ & $11.644,44 \pm 6,757$ & 0,458 \\
Albumin $\mathrm{mg} / \mathrm{dL}$ & $3,08 \pm 0,74$ & $3,56 \pm 0,99$ & $0,019^{*}$ \\
\hline
\end{tabular}

*signifikan bila $\mathrm{p}<0.05$

Tabel 4. Risiko relatif pada dua kelompok

\begin{tabular}{|c|c|c|c|c|}
\hline \multirow{2}{*}{ Anak gizi buruk yang berisiko } & & \multicolumn{2}{|c|}{ Infeksi } & \multirow{2}{*}{ Total } \\
\hline & & Positif & Negatif & \\
\hline \multirow[t]{2}{*}{ Hipoalbuminemia } & Positif $(<3,0)$ & 22 & 10 & 32 \\
\hline & Negatif $(=3,0)$ & 23 & 22 & 45 \\
\hline Total & & 45 & 32 & 77 \\
\hline
\end{tabular}

Risiko relatif :1,35, CI 95\%:1,030-1,946

persentase berat badan ideal, pada pasien gizi buruk, baik pada kelompok penyakit infeksi maupun non infeksi.

Dari 45 anak gizi buruk dengan penyakit infeksi, didapatkan 19 laki-laki dan 26 perempuan. Sedangkan dari 32 pasien gizi buruk dengan penyakit non infeksi didapatkan 20 laki-laki dan perempuan. Rerata usia napas atas dan infeksi saluran kencing. Sedangkan untuk penyakit non infeksi yang terbanyak didominasi kelainan jantung (84,37\%) (Tabel 2).

Tidak ada perbedaan yang bermakna antara kadar hemoglobin dan jumlah leukosit di antara dua kelompok tersebut (Tabel 3). Namun, didapatkan perbedaan yang bermakna $(\mathrm{p}=0,019)$ pada rerata 


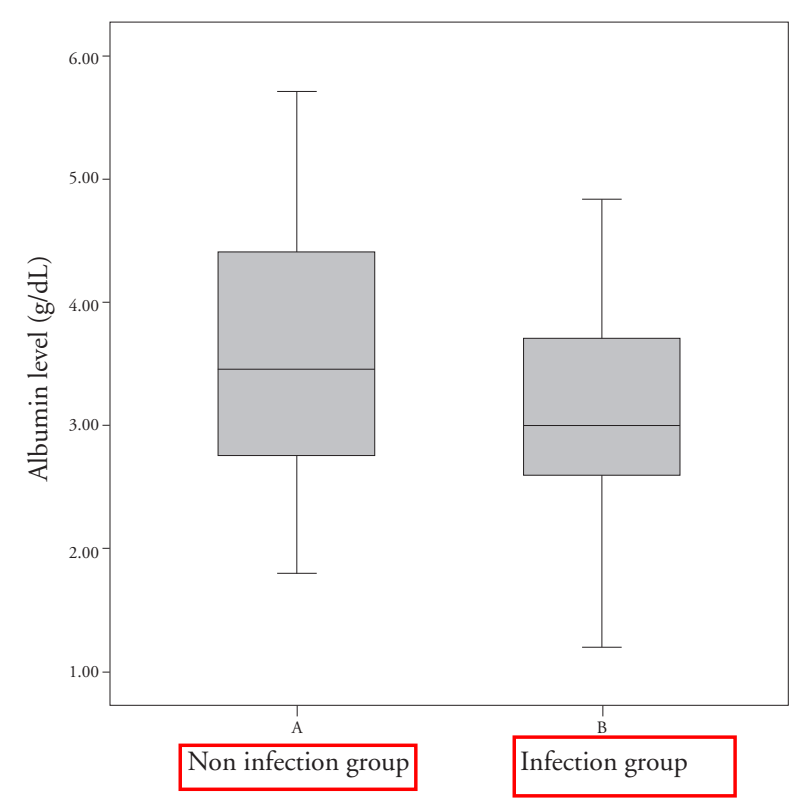

Gambar 1. Box plot kadar serum albumin pada dua kelompok

kadar albumin pada kelompok infeksi lebih rendah dibandingkan kelompok non infeksi.

Tabel 4 dan Gambar 1 menunjukkan risiko relatif pada kelompok anak gizi buruk dengan penyakit infeksi dan kelompok gizi buruk dengan penyakit non infeksi didapatkan kelompok anak gizi buruk dengan serum albumin rendah mempunyai risiko untuk mendapatkan penyakit infeksi lebih tinggi dibanding anak gizi buruk tanpa penyakit infeksi (RR:1.35, CI 95\%:1.030-1.946).

\section{Pembahasan}

Seperti yang dinyatakan beberapa penulis bahwa terjadi penurunan kadar albumin pada anak dengan gizi buruk yang disebabkan penurunan sintesis protein total, dan peningkatan pemecahan yang menyebabkan penurunan kadar albumin dalam tubuh. Penurunan kadar albumin dalam tubuh tersebut berhubungan dengan peningkatan risiko infeksi. ${ }^{10,11}$

Penyakit infeksi sering menyertai anak dengan gizi buruk. Infeksi dapat memperberat penurunan albumin karena adanya peningkatan konsentrasi sitokin pada proses infeksi. ${ }^{12,13}$ Pada penelitian kami, penyakit infeksi yang menyertai anak gizi buruk terbanyak adalah diare $(42,22 \%)$ dan disusul dengan infeksi saluran napas bawah sekitar 26,66\%. Beberapa penelitian sebelumnya oleh Hamidu ${ }^{13}$ didapatkan hasil yang hampir sama, infeksi terbanyak yang menyertai anak gizi buruk adalah diare $(41,6 \%)$, begitu juga dengan penelitian oleh Najeera ${ }^{14}$ didapatkan infeksi terbanyak pada gizi buruk adalah diare sekitar 40\%. $\mathrm{Hal}$ ini berhubungan dengan higiene sanitasi yang buruk pada sebagian besar anak gizi buruk dengan sosio ekonomi yang rendah,

Kami mendapatkan anak gizi buruk dengan penyakit infeksi mempunyai kadar albumin yang lebih rendah dibandingkan anak gizi buruk dengan penyakit non infeksi. Hasil yang sama dari penelitian sebelumnya yang dilakukan oleh Rahman $\mathrm{dkk}^{15}$, juga didapatkan kadar albumin yang lebih rendah pada anak gizi buruk dengan penyakit infeksi dibandingkan anak gizi baik yang disertai penyakit infeksi. Hal tersebut disebabkan karena infeksi akan menurunkan kadar albumin. Pada anak dengan gizi buruk sebelumnya mempunyai kadar yang lebih rendah dibandingkan anak dengan gizi baik. ${ }^{16}$

Penelitian lain oleh Suliman $\mathrm{dkk}^{16}$ dengan subyek penelitian anak gizi buruk dari Sudan yang membandingkan kadar albumin pada pasien gizi buruk disertai penyakit infeksi dan anak gizi buruk disertai penyakit non infeksi. Pada anak gizi buruk dengan penyakit infeksi, terjadi penurunan kadar albumin, tetapi hanya pada penyakit infeksi diare yang disebabkan infeksi parasit. ${ }^{7}$, Tidak terdapat perbedaan penurunan albumin antara anak gizi buruk dengan penyakit infeksi diare dibandingkan gizi buruk dengan penyakit non infeksi, kecuali pada diare karena infeksi parasit. Kadar albumin yang rendah pada anak gizi buruk disebabkan penurunan sintesis albumin. Faktor lain yang berpengaruh adalah adanya infeksi dapat menurunkan metabolisme dan sintesis plasma protein akibat stimulasi sintesis sitokin seperti tumor necrosis factor a (TNF-a), interleukin 1 (IL-l), and $I L-6.)^{8,10,16}$ Sintesis sitokin ini dapat distimulasi endotoksin, eksotoksin bakteri, jamur, dan virus, atau peningkatan konsentrasi sitokin lain., ${ }^{8,10,16}$ Oleh karena itu, adanya penurunan titer infeksi pada anak gizi buruk karena terapi antibiotik akan menurunkan produksi sitokin dan akan meningkatkan albumin., ${ }^{9,16}$ Selama periode stres akibat respon terhadap infeksi, terjadi peningkatan pemecahan protein dan adanya balans nitrogen negatif yang akan menyebabkan penurunan konsentrasi albumin pada fase akut dan atau peningkatan pengeluaran dari pembuluh darah 
kapiler. ${ }^{6,16}$ Keberadaan efek toksik dari radikal bebas menyebabkan kerusakan sel yang berakibat terjadinya hipoalbuminemia. ${ }^{6,16}$

Hasil pada penelitian kami tidak sama dengan penelitian yang dilakukan oleh Sulimandkk. Pada penelitian kami, penurunan kadar albumin terjadi pada semua penyakit infeksi termasuk infeksi diare, tetapi tidak dibedakan antara infeksi parasit atau infeksi bukan karena penyakit parasit. Pada infeksi diare yang disebabkan parasit, terjadi peningkatan pengeluaran albumin pada feses yang disebabkan toksin parasit. Hal tersebut akan berpengaruh terhadap kerusakan sel usus dan mengakibatkan peningkatan pengeluaran albumin dari pembuluh darah kapiler di usus. Selain gangguan sintesis albumin yang disebabkan penurunan metabolisme dan sintesis plasma protein akibat stimulasi sintesis sitokin, kadar albumin akan lebih menurun dibandingkan diare yang bukan karena infeksi parasit. ${ }^{7,816}$

\section{Kesimpulan}

Pada anak gizi buruk yang mempunyai kadar albumin rendah dan dirawat di rumah sakit, lebih berisiko untuk mendapatkan infeksi sehingga diperlukan kewaspadaan bagi klinisi untuk mencegah komplikasi klinis yang lebih berat

\section{Daftar pustaka}

1. Baron M, Hudson M, Steele R. Is serum albumin a marker of malnutrition in chronic disease?the scleroderma paradigm. J Am Coll Nutr 2010;29:14451

2. Morlese J, Forrester T, Jahoor F. Acute-Phase Protein response to infection in severe malnutrition. Am J Physiol Endocrinol Metab 1998;275:112-17

3. Shenkin. Serum Prealbumin:Marker of status or risk?. Clinical Chemistry 2006;52:2177-79

4. Fergusson RP, O'Connor P, Crabtree B, Batchelor A, Mitchell J. Coppola D. Serum albumin and prealbumin as predictors of clinical outcomes of hospitalized elderly nursing from home residents. J Am Geriatr Soc 1993; 41:545-9

5. Manary MJ, Brewster DR, Broadhead RL, Crowley JR, Fjeld CR, Yarasheski KE. Protein metabolism in children with edematous malnutrition and acute respiratory infection. Am J Clin Nutr, 1997;65:1005-10.

6. Reid M, Badaloo A, ForresterT, Morlese JF, Heird WC, Jahoor F.The acute-phase protein response to infection in edematous and nonedematous protein-energy malnutrition. Am J Clin Nutr 2002;76:1409-15.

7. Hughes, Kelly. Interactions of malnutrition and immune impairment, with specific reference to immunity against parasites.Parasite Immunol 2006;28:577-88.

8. Keusch GT. The History of Nutrition:Malnutrition, Infection, and Immunity. Symposium: Nutrition and Infection, Prologue and Progress Since 1968. JNutr 2003; 133:336-40.

9. Schaible UE, Kauffmann SH. Malnutrition and Infection: Complex mechanism and global impact. Journal pmed 2007;4:806-12.

10. Yoon PW, Black RE, Moulton FH, Becker S. The effect of malnutrition on the risk of diarrheal and respiratory mortality in children $<2$ y of age in Cebu, Philippines. Am J Clin Nutr 1997;65:1070-7.

11. Rahman A, Manan A, Rahman M. Influence of infection oniron profile in severly malnourished children. Indian J Pediatr 2009;76:907-11.

12. Field CJ, Johnson IR, Schley PD. Nutrients and their role in host resistance to infection. J Leukocyte Biol, 2002;71:16-32.

13. Hamidu, JL, Salami HA, Ekanem AU and Hamman. Prevalence of protein energy malnutrition in Maiduguri Nigeria. Afr J Biomed Res 2003; 6:123.

14. Najera O,Cristina G,Guadalupe T,Laura L. Flow Cytometry Study of Lymphocyte Subsets in Malnourished and WellNourished Children with Bacterial Infections. Clin and Diag Lab Immunol 2004; 11: 577-580.

15. Rahman A, Manan A, Rahman M.Serum Iron and total iron binding capacity in severely malnourished children. Bangladesh J Pharmacol 2007;2:61-5.

16. Suliman O, Salih M, Karrar Z, Mohammed A, Helsing C. Acute phase reactants in Sudanese children with severe protein-energy malnutrition. Sudan J Paediatr 2011;11:49-59. 